\title{
Slope aspect influences plant biomass, soil properties and microbial composition in alpine meadow on the Qinghai- Tibetan Plateau
}

\author{
Ran Xue ${ }^{1}$, Qian Yang ${ }^{1}$, Fuhong Miao ${ }^{2}$, Xianzhi Wang ${ }^{1}$, Yuying Shen ${ }^{1 *}$

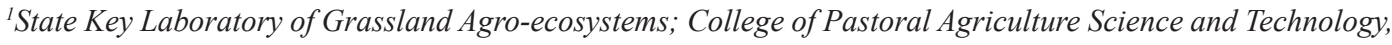 \\ Lanzhou University, National Demonstration Center for Experimental Grassland Science Education. Lanzhou \\ 730020, China. ${ }^{2}$ College of Animal Science and Technology, Qingdao Agriculture University, Qingdao 266109, \\ China. *Corresponding author: yy.shen@lzu.edu.cn
}

\begin{abstract}
Difference in soil moisture, temperature and microclimate on sunny and shady slope aspect can lead to various plant community, sequentially modify soil microbial community. In this study, we measured soil properties including soil temperature, soil moisture, soil organic carbon (SOC), total nitrogen (TN); plant properties including aboveground and underground biomass, and microbial properties including microbial carbon $(\mathrm{C})$, nitrogen (N) content and phospholipid fatty acids (PLFAs) to evaluate the effects of slope aspect on plant biomass, soil properties and microbial community in the alpine meadow on the Qinghai-Tibetan Plateau. The results showed that sunny sites had higher soil temperature, organic $\mathrm{C}$ and underground biomass (UB), while shady sites had higher soil moisture, TN and aboveground biomass (AB). Principal component analysis (PCA) indicated that bacteria were the dominant soil microbes at sunny sites, while the fungi was more abundant at sites with a shady aspect. Redundancy analysis (RDA) showed that temperature was the major factor affecting the composition of the microbial community. It can be concluded, that slope aspect can significantly alter microbial composition due to the differences in plant community, soil properties and especially environmental factors.
\end{abstract}

Keywords: Slope aspect, microbial community, phospholipid fatty acids, plant biomass, soil property. 


\section{Introduction}

The Qinghai-Tibetan Plateau is a very large land unit and an important terrestrial ecosystem that is known for its harsh climate, which is related to its high altitude. As the most widely distributed grassland type, alpine meadow is highly representative of the Qinghai-Tibetan plateau, and accounts for approximately half of its total area. Alpine meadow is the basis of livestock production for local herders. However, it has been degraded because of overgrazing by yaks and Tibetan sheep in recent decades. Overgrazing has not only reduced grassland productivity, but has also affected the composition and activity of microbial community because of changes in the litter decomposition rate (Abril and Bucher, 1999).

Soil properties are closely linked to the materials from which soil is derived (Tsui et al., 2004). Soil microclimate conditions (e.g., soil temperature and moisture) on different types of slopes can also affect soil development and processes (Egli et al., 2006). Slope aspect is a major topographical feature and is an important factor in grassland systems because it is more stable than other variables such as climatic factors and plant communities (Carletti et al., 2009). Nahidan et al. (2015) established that slope aspect can significantly affect the quantity of SOC, TN, and enzyme activity by altering the rate of litter decomposition and the activity of soil microbes. Soil nutrient conditions, especially $\mathrm{C}$ and nitrogen $\mathrm{N}$ contents, are affected by slope aspect, which are among the most important factors shaping soil microbial activity. Generally, the dynamic composition and activity of the soil microbial community are essential for $\mathrm{C}$ turnover (Melero et al., 2006). Differences in the quantity and quality of SOC caused by different farming systems and management practices have been well studied in mountainous landscapes. $\mathrm{N}$ is another important soil nutrient that affects plant growth and water use efficiency (Sardans et al., 2008). Huang et al. (2015) found that soil $\mathrm{N}$ was one of the most sensitive indicators for the microbial community at sites with different slope aspects. Slope aspect also affects plant density and plant species diversity. Species richness and biomass were shown to differ between sites with sunny and shady aspects (Badano et al., 2005; Gong et al., 2008). The plant community shapes the variety and quantity of microbes in soil community, as a result of different types of litter, root cell components, and root exudates (Bardgett et al., 1999; Steenwerth et al., 2002; Leifeld et al., 2013). Increasing plant species richness can diversify soil microbial community via effects on soil nutrient pool and nutrient cycling rate, especially the distribution and cycling of $\mathrm{C}$ and $\mathrm{N}$ (Chung et al., 2007). Plant and root residues also provide substrates for microbial community (Xue et al., 2016; Xue et al., 2017). Therefore, plant community is one of the most important factors when investigating the size and composition of microbial community in soil at sites with different slope aspects. Therefore, when studying the properties of the soil microbial community in a mountainous region, it is important to consider the effects of slope on plant community.

Most studies on slope aspect have focused on its effects on plant communities and grassland productivity. However, few studies have focused on the effects of slope aspect on soil nutrient conditions and microbial community, especially in the harsh conditions on the Qinghai-Tibetan Plateau. Thus, the aims of this study were as follows: 1) to investigate the relationship between slope aspect (sunny or shady) on microbial biomass and microbial community structure by analyzing PLFAs; and 2) to explore the relationships between slope aspect and plant biomass, soil chemical and physical properties, and microbial groups. Future work will investigate the relationships between slope 
aspect and soil microbial properties for the sustainable development of alpine meadow ecosystems on the Qinghai-Tibetan Plateau.

\section{Material and Methods}

\subsection{Experimental area}

The experimental site was located in the Zhuaxixiulong grassland, which is part of the alpine meadow on the northeast edge of Qinghai-Tibetan Plateau $\left(102^{\circ} 29^{\prime}-102^{\circ} 33^{\prime} \mathrm{E}, 37^{\circ} 11^{\prime}-37^{\circ} 12^{\prime} \mathrm{N}, 2990 \mathrm{~m}\right.$ above sea level). The annual precipitation at this site ranges from 265 to $630 \mathrm{~mm}$ and rainfall is typically highest during June to August. The annual mean temperature ranges from -0.2 to $1.3{ }^{\circ} \mathrm{C}$, with a 100 -day growing season. The soil texture at this site is primarily Mollisol (USDA, 2010). The vegetation of the alpine meadow in this area consists of Kobresia capillifolia C.B. Clarke, Polygonum viviparum L., Festuca ovina L., Pedicularis kansuensis Maxim, and other alpine grasses. The plant community at the site with a sunny aspect consisted primarily of $K$. capillifolia, F. ovina and Elymus nutans, and that at the site with a shady aspect consisted of P. viviparum and Kobresia tibeti$c a$. This meadow had been short-term grazed by yaks from June to September in the three years before this study was conducted.

\subsection{Soil and plant sampling}

In mid-August, when plant community reached its maximum aboveground biomass (AB), nine soil and plant samples were randomly collected from two sites with different aspects: one with a sunny aspect and the other with a shady aspect. The sites were both about 12 ha and there was at least $100 \mathrm{~m}$ between sampling locations. Soil samples were collected from 0-20 cm layer and then root fragments, stones, and vegetation were separated using a 2-mm sieve. Soil samples for microbial community analyses were immediately frozen at $-20{ }^{\circ} \mathrm{C}$; samples for microbial carbon and nitrogen $\left(\mathrm{C}_{\text {mic }}\right.$ and $\left.\mathrm{N}_{\text {mic }}\right)$ analyses were stored at $4{ }^{\circ} \mathrm{C}$; and samples for other analyses of other chemical properties were air-dried to constant weight. The AB was measured within quadrats $(1 \mathrm{~m} \times 1 \mathrm{~m})$ and underground biomass (UB) was measured by a soil auger down to $30 \mathrm{~cm}$. Plant samples were dried in an oven at $85^{\circ} \mathrm{C}$ for $48 \mathrm{~h}$ and then weighed.

\subsection{Measurement of soil properties}

Soil temperature was measured using a soil thermometer when the soil samples were collected. Soil moisture was measured by oven-drying soil samples at 105 ${ }^{\circ} \mathrm{C}$ for $72 \mathrm{~h}$. SOC was determined by dichromate oxidation and titration with ferrous ammonium sulfate, and $\mathrm{TN}$ was determined using an automatic analyzer (Kjeltec 8400, FOSS, Hoganas, Sweden) using the Kjeldahl method (Bremner and Mulvaney, 1982). We determined $\mathrm{C}_{\text {mic }}$ and $\mathrm{N}_{\text {mic }}$ using the chloroform fumigation extraction method (Brookes et al., 1985; Wu et al., 1990), in which $\mathrm{K}_{2} \mathrm{SO}_{4}$ soil extracts of fumigated and unfumigated soil samples were kept in a vacuum desiccator for 24 hours. We calculated Nmic by determining ammonium nitrogen using a continuous flow analyzer (FIAstar 5000 Analyzer, FOSS, Sweden), and calculated $\mathrm{C}_{\text {mic }}$ after dichromate oxidation and titration with ferrous ammonium sulfate.

\subsection{Phospholipid fatty acids analysis}

The PLFAs were extracted from $5 \mathrm{~g}$ soil sub-samples according to the procedure of Bligh and Dyer (1959). Briefly, soil lipids were extracted using a mixture of chloroform, methanol, and $0.15 \mathrm{M}$ citrate buffer $(1: 2: 0.8 \mathrm{v} / \mathrm{v} / \mathrm{v})$. The non-polar phase was loaded onto a silica-bonded phase extraction column and separated 
into neutral lipid, glycolipid, and phospholipid fractions by sequential elution with chloroform, acetone, and methanol. Phospholipids were methylated by adding methanol-toluol and $0.2 \mathrm{~mol} / \mathrm{L} \mathrm{KOH}$ solution. Samples were then analyzed by gas chromatography - mass spectrometry using an Agilent 6890-5973N system (Agilent Technologies, Wilmington DE, USA) and the separated components were identified using MSD ChemStation software. The PLFAs were quantified by using PLFA 19:0 as an internal standard.

Individual PLFA markers represent specific microbial groups. Total PLFAs were considered as an index of total microbial biomass using both identified and unidentified PLFAs. The sum of i14, i15:0, a15:0, 15:0, i16:0, 16:1w7, i17:0, a17:0, cy17, 17:0, and 18:1w7 was considered as an index of bacterial biomass (Frostegård and Bååth, 1996). The PLFAs i14, i15:0, a15:0, i16:0, i17:0, a17:0 represented Gram-positive $\left(\mathrm{G}^{+}\right)$bacteria and cy17 and 16:1w7 represented Gramnegative $\left(\mathrm{G}^{-}\right)$bacteria (Kourtev et al., 2002; Kaur et al., 2005). The quantity of 18:2w6.9 PLFAs was used as an index of fungal biomass. Actinomycetes biomass was estimated from the PLFA 10Me17:0. The ratio of fungal to bacterial PLFAs was used as a relative index of fungal to bacterial biomass, and the ratio of $\mathrm{G}^{+}$to $\mathrm{G}^{-}$bacteria was also calculated.

\subsection{Statistical analysis}

The effects of slope aspect on soil temperature, soil moisture, $\mathrm{SOC}, \mathrm{TN}, \mathrm{C}_{\text {mic }}, \mathrm{N}_{\text {mic }}$, and PLFA markers were analyzed by SPSS 20.0 software (SPSS Inc., Chicago, IL, USA). Mean values were compared by t-test, with $\mathrm{P}<0.05$ as the level of significance. The relationships between slope aspect and individual PLFA markers were analyzed by a principal component analysis (PCA) and the relationship between the microbial community and environmental variables at sites with sunny and shady aspects was analyzed by a redundancy analysis (RDA), using CANOCO 4.5 software (Microcomputer Power, Ithaca, NY, USA). The significance of variables was also evaluated by a Monte Carlo test.

\section{Results}

\subsection{Soil properties and plant biomass}

Soil properties and plant biomass varied between shady and sunny slopes (Table 1). Sunny slope had higher temperature, SOC, $\mathrm{C} / \mathrm{N}, \mathrm{C}_{\text {mic }}, \mathrm{C}_{\text {mic }} / \mathrm{N}_{\text {mic }}$, and $\mathrm{UB}$, while shady slope had higher soil moisture, TN, and $\mathrm{AB}$. Compared with shady slope, sunny slope had $35.6 \%$ higher soil temperature and $24 \%$ higher $\mathrm{C}_{\text {mic }}$ $(p<0.05)$. Soil moisture and TN were $27 \%$ and $15 \%$ higher, respectively, on shady slope than on sunny slope $(\mathrm{P}<0.05)$. UB was much greater than $\mathrm{AB}$ on both slopes, but the difference between $A B$ and $U B$ was larger on sunny slope, where UB was almost 25 times larger than $\mathrm{AB}$ (Figure 1). Compared with shady slope, sunny slope had significantly higher UB and lower $\mathrm{AB}(\mathrm{P}<0.05)$. 
Table 1. Soil properties at sites with a shady and sunny aspect in an alpine meadow.

\begin{tabular}{ccc}
\hline \multirow{2}{*}{ Soil property } & \multicolumn{2}{c}{ Site aspect } \\
\cline { 2 - 3 } & Sunny & Shady \\
\hline Soil temperature $\left({ }^{\circ} \mathrm{C}\right)$ & $19.43 \pm 0.48 \mathrm{a}$ & $14.33 \pm 0.51 \mathrm{~b}$ \\
Soil moisture $(\%)$ & $0.37 \pm 0.01 \mathrm{~b}$ & $0.47 \pm 0.02 \mathrm{a}$ \\
$\mathrm{SOC}\left(\mathrm{g} \mathrm{kg}^{-1}\right)$ & $61.76 \pm 1.23 \mathrm{a}$ & $57.34 \pm 0.73 \mathrm{~b}$ \\
$\mathrm{TN}\left(\mathrm{g} \mathrm{kg}^{-1}\right)$ & $4.44 \pm 0.084 \mathrm{~b}$ & $5.09 \pm 0.11 \mathrm{a}$ \\
$\mathrm{C} / \mathrm{N}$ & $13.92 \pm 0.22 \mathrm{a}$ & $11.29 \pm 0.14 \mathrm{~b}$ \\
$\mathrm{C}_{\text {mic }}\left(\mathrm{mg} \mathrm{kg}^{-1}\right)$ & $292.36 \pm 11.44 \mathrm{a}$ & $236.51 \pm 10.42 \mathrm{~b}$ \\
$\mathrm{~N}_{\text {mic }}\left(\mathrm{mg} \mathrm{kg}^{-1}\right)$ & $130.99 \pm 9.86 \mathrm{a}$ & $133.51 \pm 7.2 \mathrm{a}$ \\
$\mathrm{C}_{\text {mic }} / \mathrm{N}_{\text {mic }}$ & $2.32 \pm 0.18 \mathrm{a}$ & $1.81 \pm 0.12 \mathrm{~b}$
\end{tabular}

SOC: soil organic carbon; $\mathrm{TN}$ : total nitrogen; $\mathrm{C} / \mathrm{N}$ : soil organic carbon/total nitrogen; Cmic: microbial biomass carbon; Nmic: microbial biomass nitrogen. Nine replicates were analyzed for each aspect. Standard errors are shown. Different letters (a, b) represent significant difference between sunny and shady aspects $(\mathrm{P}<0.05$, t-test).

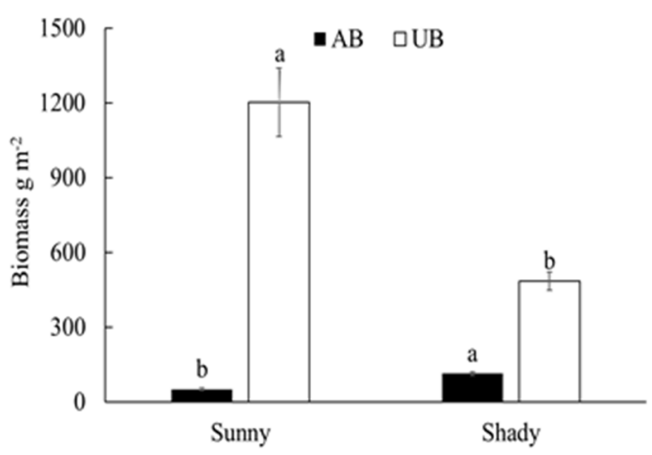

Figure 1. Aboveground and underground biomass at sites with a shady and sunny aspect in an alpine meadow. Nine replicates from each site were analyzed. Standard errors are shown. Different letters (a, b) represent significant difference between sunny and shady aspects $(\mathrm{P}<0.05$, t-test $)$. 


\subsection{Microbial community size and composition}

Microbial biomass, measured by total PLFAs, was greater on sunny slope than on shady slope (Table 2 ). Bacteria accounted for approximately $40 \%$ of total PLFA, while fungi and actinomycetes represented only about $3 \%-4 \%$. Of the bacteria, about $60 \%$ were $\mathrm{G}^{+}$and about $10 \%$ were $\mathrm{G}^{-}$on both slopes.
The amounts of bacterial, $\mathrm{G}^{+}$, and $\mathrm{G}^{-}$PLFAs were all significantly greater on sunny slope than shady slope $(\mathrm{P}<0.05)$. However, the amount of fungal PLFAs was more than $33 \%$ higher on shady slope than on sunny slope $(p<0.05)$, which resulted in a higher $F / B$ ratio on shady slope. The amount of actinomycetes PLFAs was $21 \%$ greater on sunny slope than on shady slope, but this difference was not statistically significant.

Table 2. Relative abundance of bacterial, fungal, actinomycetes phospholipid fatty acids in soil at sites with a shady and sunny aspect in an alpine meadow.

\begin{tabular}{ccc}
\hline Microbial groups & \multicolumn{2}{c}{ Site aspect } \\
\cline { 2 - 3 }$($ PLFAs) & Sunny & Shady \\
\hline Total $\left(\mathrm{nmol} \mathrm{g}^{-1}\right)$ & $712.05 \pm 19.80 \mathrm{a}$ & $674.47 \pm 12.10 \mathrm{~b}$ \\
Bacterial $\left(\mathrm{nmol} \mathrm{g}^{-1}\right)$ & $281.00 \pm 9.89 \mathrm{a}$ & $248.71 \pm 5.25 \mathrm{~b}$ \\
Gram-positive $\left(\mathrm{nmol} \mathrm{g}^{-1}\right)$ & $186.7 \pm 5.32 \mathrm{a}$ & $154.75 \pm 4.48 \mathrm{~b}$ \\
Gram-negative $\left(\mathrm{nmol} \mathrm{g}^{-1}\right)$ & $28.16 \pm 1.15 \mathrm{a}$ & $25.62 \pm 0.49 \mathrm{~b}$ \\
$\mathrm{G}^{+} / \mathrm{G}^{-}$ & $6.67 \pm 0.18 \mathrm{a}$ & $6.04 \pm 0.13 \mathrm{~b}$ \\
Fungal $\left(\mathrm{nmol} \mathrm{g}^{-1}\right)$ & $8.90 \pm 0.96 \mathrm{~b}$ & $13.56 \pm 0.80 \mathrm{a}$ \\
$\mathrm{F} / \mathrm{B}$ & $0.031 \pm 0.003 \mathrm{~b}$ & $0.055 \pm 0.003 \mathrm{a}$ \\
Actinomycetes $\left(\mathrm{nmol} \mathrm{g}^{-1}\right)$ & $14.58 \pm 1.42 \mathrm{a}$ & $12.00 \pm 1.03 \mathrm{a}$ \\
\hline
\end{tabular}

Nine replicates from each site were analyzed. Standard errors are shown. Different letters $(a, b)$ represent significant difference between sunny and shady aspects $(\mathrm{P}<0.05$, t-test).

\subsection{Principal component analysis and redundancy analysis}

PCA was conducted to analyze the effect of slope aspect on PLFA biomarker composition (Figure 2). The results showed that $\mathrm{PC} 1$ accounted for $71 \%$ and $\mathrm{PC} 2$ accounted for $13.5 \%$ of total variance. PCA scores along axis 2 showed a significant slope aspect effect (ANOVA, $\mathrm{P}<0.001$ ). The experimental sites were separated along $\mathrm{PC} 2$, where sites with a shady aspect had higher PC2 scores (most of them above X-axis), which represented higher soil moisture content and higher AB. The sites with a sunny aspect were distributed below the $\mathrm{X}$-axis, and were represented by higher temperature, $\mathrm{SOC}, \mathrm{C}_{\text {mic }}$ and UB. On the biplot of fatty acid scores based on this composite analysis, the PLFAs 18:2w6.9, 18:1w8, and 16:1w5 were relatively more abundant at sites with a shady aspect, while most of the other PLFAs were strongly enriched at sites with a sunny aspect. 


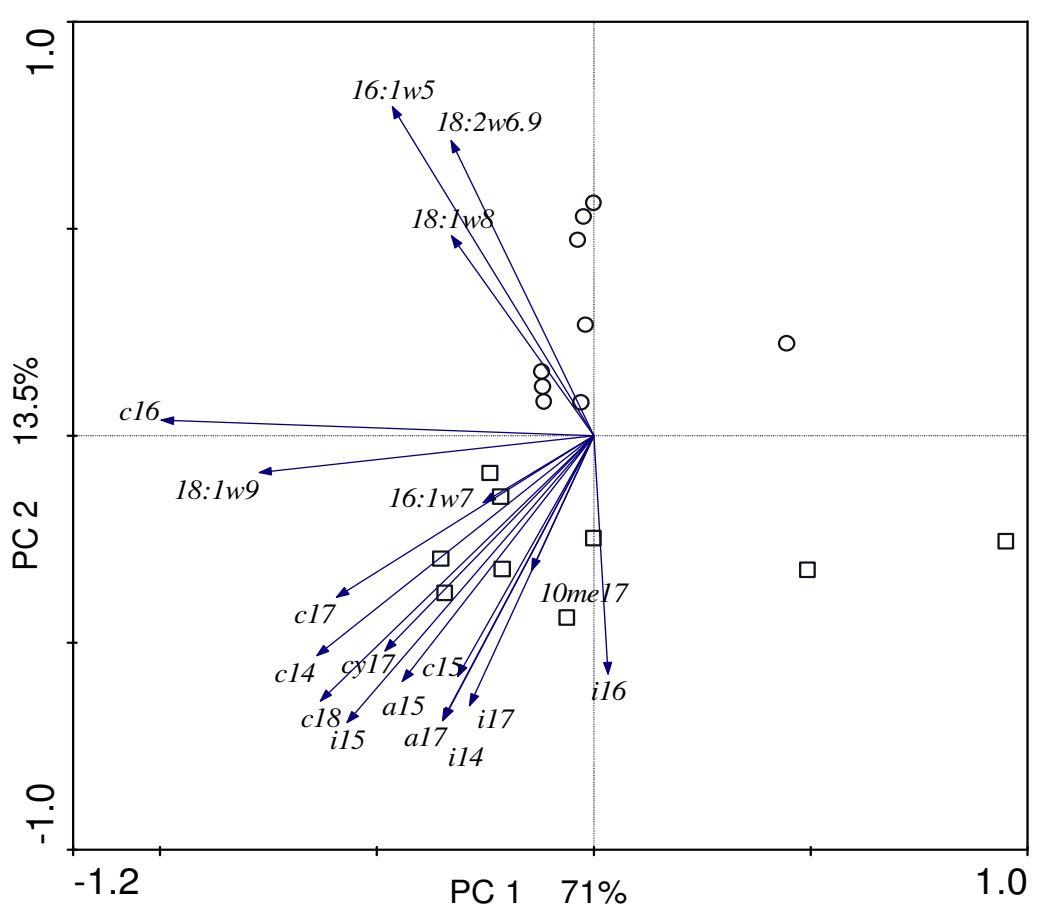

Figure 2. Loading for first two principal components (PC1 and PC2) of 18 phospholipid fatty acids (PLFA): PC1 explained $71 \%$ and $\mathrm{PC} 213.5 \%$ of the total variance in the principal component analysis. Score plot of principal component analysis showing the separation of nine sites with different slope aspect and distribution of individual phospholipid fatty acid markers ( $\square$ sunny aspect; oshady aspect).

The relationships between environmental variables and variations in the PLFA data were tested by RDA. The environmental variables analyzed were soil temperature, soil moisture, $\mathrm{SOC}, \mathrm{TN}, \mathrm{AB}$, and UB. The RDA biplots show the relationships between environmental variables and PLFA contents (Figure 3). Axis 1 explained $91.7 \%$ of the total variance in the speciesenvironment relationship, and axis 2 explained $7.2 \%$. The first ordination RDA axis was strongly correlated with temperature and $\mathrm{TN}$, while the second ordina- tion RDA axis was strongly correlated with $\mathrm{AB}$ and UB. The results of the Monte Carlo test showed that temperature $(\mathrm{F}=5.34, \mathrm{P}=0.04)$ was the main environmental factor explaining the variations in PLFAs in sites with different slope aspects. Total, bacterial, $\mathrm{G}^{+}, \mathrm{G}^{-}$, and actinomycetes PLFA biomarkers were all positively correlated with temperature and UB, while fungal PLFAs were positively correlated with $\mathrm{AB}, \mathrm{TN}$, and soil moisture. 


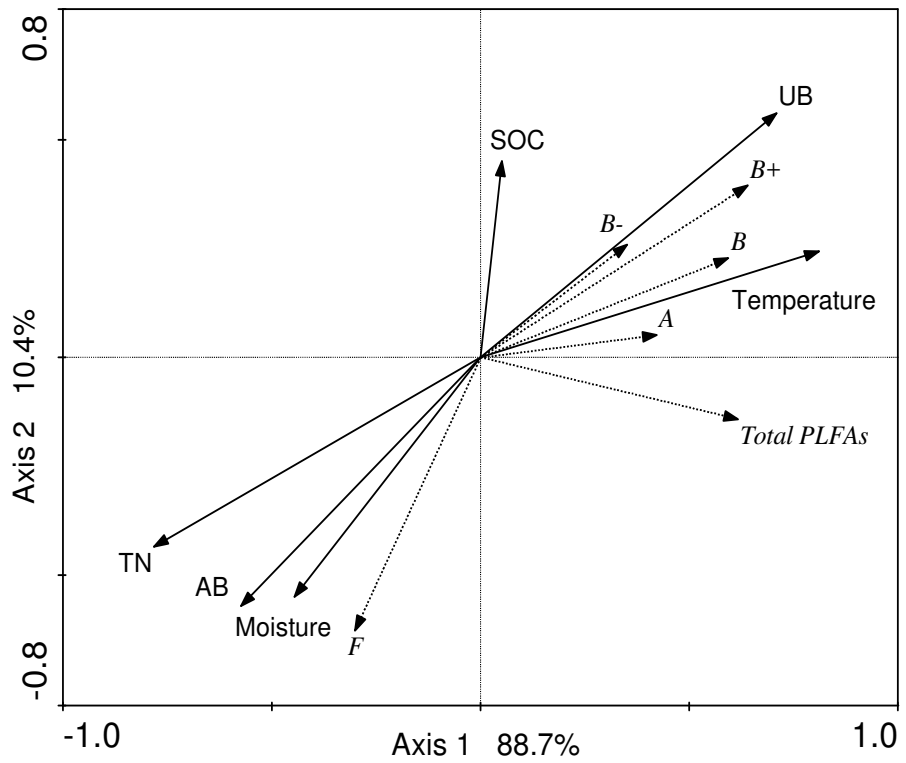

Figure 3. Redundancy analysis plot of relationship between microbial groups and environmental variables: axis 1 explained $88.7 \%$ of the variation in relative abundance of PLFA markers, axis 2 explained $10.4 \%$ (B: bacteria, F: fungi, A: actinomycetes).

\section{Discussion}

\subsection{Effect of slope aspect of plant community}

Slope aspect is known to affect the diversity and density of plant communities. Sunny slopes retain less moisture because of stronger solar radiation and higher evaporation. Therefore, plants on sunny slopes, such as grasses, are more likely to be drought- and radiation-resistant. Conversely, shade-loving plants such as forbs are dominant on shady slopes. NadalRomero et al. (2014) found a decrease in vegetation cover and species richness at sites with a shady aspect. Badano et al. (2005) also found that sunny sites were dominated by spiny shrubs and cacti while evergreen trees dominated shady slopes because of the more mesic conditions at these site.
At our study site, the differences in water distribution, temperature, and solar radiation between sunny and shady slopes resulted in different plant communities, with the dominant plant species being $K . \mathrm{ca}$ pillifolia on sunny slope and $P$. viviparum on shady slope. Therefore, there was a large difference in UB and $A B$ between sunny and shady slopes. Also, the morphological characteristics of the dominant plant species differed between sunny and shady slopes. For example, $K$. capillifolia has a fibrous root, while $P$. viviparum has a tap root. Differences between these two root systems include root turnover rates, root exudates, and absorption and utilization of carbon, which may directly or indirectly influence SOC in the rhizosphere soil of different plants (Aprill and Sims, 1990). Therefore, differences in the characteristics of the dominant species may explain why plant biomass 
and soil properties differed markedly between sunny and shady slopes in our study.

\subsection{Effect of slope aspect on soil properties}

Total plant biomass was higher on sunny slope, which may have led to higher SOC and consequently, adequate substrates for microbes. However, Huang et al. (2015) obtained the opposite result in the Loess Plateau region, with higher SOC detected at sites with a shady aspect. The best explanation is that moisture is the fundamental environmental factor in a relatively dry region, so higher moisture at sites with a shady aspect may lead to better nutrient cycling and higher activity of the microbial community. However, in cold and wet areas such as alpine meadows, temperature or the amount of radiation will be more important environmental factors, and so the higher temperatures at sites with a sunny aspect will lead to higher microbial activity and better soil nutritional status.

Soil microbes can be very sensitive to temperature. In cold systems like plateaus, sites with a sunny aspect receive more solar radiation and have temperatures that are more suitable for microbial growth. Also, soil moisture controls the survival and activity of microorganisms (Drenovsky et al., 2004; Borken and Matzner, 2009). At our study site, precipitation was very high when soil was collected, and the soil moisture content on the shady slope was $43.7 \%$, which was more than enough to meet the needs of microorganisms and plants. Therefore, the microbial population on shady slope is not likely to be limited by water deficit. The relatively lower bacterial PLFA and higher fungal PLFA on shady slope than on sunny slope suggested that water potential affects microbial groups differently. In general, fungi are more tolerant than bacteria to high soil moisture content. Fungi can build airgaps in wet soil using their hyphal system, while high soil moisture content can reduce the movement of bacteria. Consequently, fungi are more likely survive at sites with a shady aspect (Wilson and Griffin, 1975; Wilkinson et al., 2002).

\subsection{Effect of slope aspect on microbial community}

While $\mathrm{C}_{\text {mic }}$ and $\mathrm{N}_{\text {mic }}$ make up only a small proportion of SOC and TN, they are the most active parts in the turnover and reproduction of the microbial community (Moore et al., 2000). In our study, $\mathrm{C}_{\text {mic }}$ and $\mathrm{N}_{\text {mic }}$ contributed $0.5 \%$ and $2.5 \%$ to SOC and TN, respectively. Cmic was higher on sunny slope than on shady slope, indicating that microbial biomass was larger on the sunny slope. PLFA biomarkers results also indicated that microbial biomass was greater on sunny slope than shady slope. The proportion of fungal PLFAs was higher on shady slope, suggesting that relatively low temperature and higher plant biomass are better for fungal growth and development, while a habitat with higher temperatures may be more suitable for bacteria.

Slope aspect affects microbial community by altering environmental factors, soil properties, and the plant community. Root exudate is the driver of microbial biomass and activity. Further, quality and identity of rhizodeposits differs from plant to plant (Barea, 2015). Thus, in this study, effect of different plant community on microbial community is also an important component of slope influence. Some researchers have argued that soil physical or chemical properties are more important than the plant community in shaping the structure of the soil microbial community. Bezemer et al. (2006) found that the effects of soil chemical properties were even greater when grasses and forbs were grown in sandy soil, while Bardgett et al. (1999) argued that the biomass and activity of the soil microbial community generally depend on soil fertility conditions within a single soil type. The results of our study indicate that while plant biomass 
may be an important factor controlling the biomass of active microbial groups, it did not outweigh the effects of soil temperature in alpine meadow ecosystem.

\section{Conclusions}

Due to the differences in environment factors (temperature and moisture), as well as plant species on sunny and shady aspect, sunny slope had higher soil organic carbon (SOC) and underground biomass (UB) while shady slope had higher total nitrogen (TN) and aboveground biomass (AB). Further, microbial composition also affected by various carbon $(\mathrm{C})$ and nitrogen $(\mathrm{N})$ utilization, cycling model and microclimate, in which bacterial phospholipid fatty acids (PLFAs) were higher in sunny slope, while fugal PLFAs were higher on shady slope. It is suggested that plant community, soil properties and environmental factors all made contribution to the microbial diversity between sunny and shady slope, among which temperature was the main factor that can explain most of the variations in alpine meadow system.

\section{Acknowledgements}

We thank Shiqing Li and Yajing Guo for assistance with the sampling and data analyses. This work was jointly supported by grants from the "Special Fund for Agro-scientific Research in the Public Interest" (200903060), China Forage\& Grass Research System (CARS-34) and by the Program for Changjiang Scholars and Innovative Research Team in Lanzhou University (IRT17R50).

\section{References}

Abril, A., Bucher, E.H. 1999. The effects of overgrazing on soil microbial community and fertility in the Chaco dry savannas of Argentina. Appl. Soil Ecol. 12, 159-167.

Aprill, W., Sims, R.C. 1990. Evaluation of the use of prairie grasses for stimulating polycyclic aromatic hydrocarbon treatment in soil. Chemosphere. 20, 253-265.

Badano, E.I., Cavieres, L.A., Molina-Montenegro, M.A., Quiroz, C.L. 2005. Slope aspect influences plant association patterns in the Mediterranean matorral of central Chile. J. Arid Environ. 62, 93-108.

Bardgett, R.D., Lovell, R.D., Hobbs, P.J., Jarvis, S.C. 1999. Seasonal changes in soil microbial communities along a fertility gradient of temperate grasslands. Soil Biol. Biochem. 31, 1021-1030.

Barea, J. 2015. Future challenges and perspectives for applying microbial biotechnology in sustainable agriculture based on a better understanding of plant-microbiome interactions. J. Soil Sci. Plant Nut. 15, 261-282.

Bezemer, T., Lawson, C.S., Hedlund, K., Edwards, A.R., Brook, A.J., Igual, J.M., Mortimer, S.R., Van Der Putten, W.H. 2006. Plant species and functional group effects on abiotic and microbial soil properties and plant-soil feedback responses in two grasslands. J. Ecol. 94, 893-904.

Bligh, E.G., Dyer, W.J. 1959. A rapid method of total lipid extraction and purification. Can. J. Biochem. Phys. 37, 911-917. 
Borken, W., Matzner, E. 2009. Reappraisal of drying and wetting effects on $\mathrm{C}$ and $\mathrm{N}$ mineralization and fluxes in soils. Global Change Biol. 15, 808-824.

Bremner, J.M., Mulvaney, C. 1982. Nitrogen-total. Methods of soil analysis. Part 2. Chemical and microbiological properties. Soil Science Society of America, Madison, WI, pp:595-624.

Brookes, P.C., Landman, A., Pruden, G., Jenkinson, D. 1985. Chloroform fumigation and the release of soil nitrogen: a rapid direct extraction method to measure microbial biomass nitrogen in soil. Soil Biol. Biochem. 17, 837-842.

Carletti, P., Vendramin, E., Pizzeghello, D., Concheri, G., Zanella, A., Nardi, S., Squartini, A. 2009. Soil humic compounds and microbial communities in six spruce forests as function of parent material, slope aspect and stand age. Plant Soil. 315, 47-65.

Chung, H., Zak, D.R., Reich, P.B., Ellsworth, D.S. 2007. Plant species richness, elevated CO2, and atmospheric nitrogen deposition alter soil microbial community composition and function. Global Change Biol. 13, 980-989.

Drenovsky, R., Vo, D., Graham, K., Scow, K. 2004. Soil water content and organic carbon availability are major determinants of soil microbial community composition. Microbial Ecol. 48, 424-430.

Egli, M., Mirabella, A., Sartori, G., Zanelli, R., Bischof, S. 2006. Effect of north and south exposure on weathering rates and clay mineral formation in Alpine soils. Catena. 67, 155-174.

Frostegård, Å., Bååth, E. 1996. The use of phospholipid fatty acid analysis to estimate bacterial and fungal biomass in soil. Biol. Fert. Soils. 22, 59-65.

Gong, X., Brueck, H., Giese, K., Zhang, L., Sattelmacher, B., Lin, S. 2008. Slope aspect has effects on productivity and species composition of hilly grassland in the Xilin River Basin, Inner Mongolia, China. J. Arid Environ. 72, 483-493.
Huang, Y.M., Liu, D., An, S.S. 2015. Effects of slope aspect on soil nitrogen and microbial properties in the Chinese Loess region. Catena. 125, 135-145.

Kaur, A., Chaudhary, A., Kaur, A., Choudhary, R., Kaushik, R. 2005. Phospholipid fatty acid - A bioindicator of environment monitoring and assessment in soil ecosystem. Curr. Sci. 89, 1103-1112.

Kourtev, P.S., Ehrenfeld, J.G., Häggblom, M. 2002. Exotic plant species alter the microbial community structure and function in the soil. Ecology. 83, 3152-3166.

Leifeld, J., Bassin, S., Conen, F., Hajdas, I., Egli, M., Fuhrer, J. 2013. Control of soil $\mathrm{pH}$ on turnover of belowground organic matter in subalpine grassland. Biogeochemistry. 112, 59-69.

Melero, S., Porras, J.C.R., Herencia, J.F., Madejon, E. 2006. Chemical and biochemical properties in a silty loam soil under conventional and organic management. Soil Till. Res. 90, 162-170.

Moore, J., Klose, S., Tabatabai, M. 2000. Soil microbial biomass carbon and nitrogen as affected by cropping systems. Biol. Fert. Soils. 31, 200-210.

Nadal-Romero, E., Petrlic, K., Verachtert, E., Bochet, E., Poesen, J. 2014. Effects of slope angle and aspect on plant cover and species richness in a humid Mediterranean badland. Earth Surf. Proc. Land. 39, 1705-1716.

Nahidan, S., Nourbakhsh, F., Mosaddeghi, M.R. 2015. Variation of soil microbial biomass $C$ and hydrolytic enzyme activities in a rangeland ecosystem: are slope aspect and position effective? Arch. Agron. Soil Sci. 61, 797-811.

Sardans, J., Peñuelas, J., Estiarte, M. 2008. Changes in soil enzymes related to $\mathrm{C}$ and $\mathrm{N}$ cycle and in soil $\mathrm{C}$ and $\mathrm{N}$ content under prolonged warming and drought in a Mediterranean shrubland. Appl. Soil Ecol. 39, 223-235. 
Steenwerth, K.L., Jackson, L.E., Calderón, F.J., Stromberg, M.R., Scow, K.M. 2002. Soil microbial community composition and land use history in cultivated and grassland ecosystems of coastal California. Soil Biol. Biochem. 34, 1599-1611.

Tsui, C.C., Chen, Z.-S., Hsieh, C.F. 2004. Relationships between soil properties and slope position in a lowland rain forest of southern Taiwan. Geoderma. 123, 131-142.

USDA, N. 2010. Keys to soil taxonomy. USDA, Washington DC, pp:197-240.

Wilkinson, S., Anderson, J., Scardelis, S., Tisiafouli, M., Taylor, A., Wolters, V. 2002. PLFA profiles of microbial communities in decomposing conifer litters subject to moisture stress. Soil Biol. Biochem. 34, 189-200.

Wilson, J.M., Griffin, D. 1975. Water potential and the respiration of microorganisms in the soil. Soil Biol. Biochem. 7, 199-204.
Wilson, J.M., Griffin, D. 1975. Water potential and the respiration of microorganisms in the soil. Soil Biol. Biochem. 7, 199-204.

Wu, J., Joergensen, R., Pommerening, B., Chaussod, R., Brookes, P. 1990. Measurement of soil microbial biomass $\mathrm{C}$ by fumigation-extraction - an automated procedure. Soil Biol. Biochem. 22, 1167-1169.

Xue, R., Shen, Y., Marschner, P. 2016. Low soil water content during plant growth influences soil respiration and microbial biomass after plant removal rewetting. J.Soil Sci. Plant Nut. 16, 955-966.

Xue, R., Shen, Y., Marschner, P. 2017. Soil water content during and after plant growth influence nutrient availability and microbial biomass. J. Soil Sci. Plant Nut. 17, 702- 715. 